\title{
Political Socialization in New Democracies: Legacies of Repression and Pre-Democratic Partisanship
}

\author{
Alexandra Domike Blackman, Nicholas Lotito, \\ Elizabeth Nugent, and Daniel Tavana
}

March 4, 2020

\begin{abstract}
Family socialization is a key mechanism for the transmission of political attitudes and behaviors. Work in developed democracies highlights the role of family socialization in the stability of partisanship across generations. But what of family socialization in new democracies? In this paper, we develop a framework for understanding how experiences with state repression and the process of family socialization influence new democracies after transition from authoritarian rule. In doing so, we combine findings from established literature on processes of family socialization with political psychological work on how repression crystallizes political identities. We examine how individual-level experiences of state repression shape political participation and partisanship in Tunisia, an important and rare contemporary case of successful (and still ongoing) democratic transition. Drawing on a nationally representative survey conducted in 2017, we find evidence that Tunisian citizens whose family and community members who were arrested are more likely to vote in subsequent democratic elections and to vote against the old regime. While individuals who were arrested under the previous authoritarian regime are less likely to turn out to vote, in line with research on the demobilizing effects of repression, those that do vote are strong partisans and are more likely to vote for the former opposition and anti-old regime parties. This paper lays out a broader project on how the different socialization processes in authoritarian regimes affect political attitudes and behaviors after democratization.
\end{abstract}

Keywords: repression, political socialization, Tunisia 
Political socialization is identified as a key mechanism for the transmission of political attitudes and behaviors. Work in developed democracies highlights the role of socialization in the stability of partisanship within families (Bengtson, 1975; Ventura, 2001; Achen, 2002; Jennings et al., 2009). And work in autocracies highlights the role of family socialization in the continuity of political values, such as authoritarianism (Pop-Eleches and Tucker, 2019), or in the consolidation of new political identities and even political opposition to the autocratic regime (Lupu and Peisakhin, 2017). One consistent finding in the literature on autocratic repression is that - while in the short term, it can instill fear and deter expressed opposition - in the long term there is typically a backlash; those individuals or communities that experienced greater state violence or repression express stronger opposition against the perpetrators (or their successors) especially after democratization (Balcells, 2011; Rozenas and Zhukov, 2019).

Munch of this work on repression in autocracies is focused on the formation and transmission of partisan preferences; however, it remains unclear how experiences with repression and, in particular, arrests, impact overall political participation, as well as the extent to which arrests have heterogeneous effects at the individual, family, and community-level. Because recent studies on the long-run effects of repression often explore these effects at the community level, these studies assume that members of these communities and families are subsequently uniformly motivated to participate in politics. However, research that looks at the more proximate effects of arrests indicate that repression can have a differential impact on participation among those who were arrested and those in the arrestee's social circle (Pan and Siegel, 2020). The heterogeneous effect of arrest on those directly and proximately affected is reflected in debates about the effect of arrest for individuals and for families in the United States (Weaver and Lerman, 2010; Walker, 2014; White, 2019b).

This article makes two contributions to our understanding of the effects of repression and the development of pre-democratization patterns of political participation and partisan- 
ship. First, this study draws attention to the experiences of repression among non-elites at the individual-level and distinguishes between individual's personal experiences with repression and their experience via their friends and family. By differentiating between repression experienced personally and by family and friends, we echo previous work on how political socialization, particularly within families, can extend and even transform the effect of individual-level repression.

Moreover, while many studies of elite repression show that repression can lead to backlash mobilization, this study also differentiates between backlash in the form of higher political engagement and backlash in terms of vote choice. The preliminary evidence presented below shows that those who suffer arrest under autocracy are not more likely to participate in politics after democratization; instead, it is the family members of those who are repressed who are more politically active. Both arrestees and their families and friends, though, are less likely to support parties associated with the old regime.

Second, the studies of arrests typically differentiate between that type of quotidian coercive state behavior in democracies and autocracies. ${ }^{1}$ We try to bridge this literature by incorporating research on the effect of arrests and interactions with the carceral state in democracies into conversation with research on repression in autocracies, as well as by connecting experiences with arrest in autocracies to political behavior after democratization.

The paper proceeds as follows. First, we situate our study in the existing literature on authoritarian repression, political socialization, particularly within the family, and subsequent political participation and partisanship. Building on the literature on the effects of repression and arrests on political behavior and family socialization, we propose a set of hypotheses to adjudicate between competing expectations. Next, we discuss repression in Tunisia, particularly during the autocratic regime of Ben Ali, focusing on how arrests were

\footnotetext{
${ }^{1}$ Certainly, there are interesting examples that reflect some of the shared experiences of state coercion across regime type. Sullivan and Davenport (2017) provide an interesting study of individual-level participation in a black-nationalist insurgency group in the United States.
} 
used to marginalize potential opponents of the regime.

Drawing on a nationally representative survey conducted in 2017, we then present initial evidence that repression matters for post-democratization political behaviors and that this relationship operates through both personal experience with repression as well as family socialization. Tunisian citizens whose family and community members were arrested are more likely to vote in subsequent democratic elections and to vote against the old regime and its successor political parties. And, while individuals who were arrested under the previous authoritarian regime are not more likely to vote, we find that those that do vote are strong partisans and are more likely to vote against political actors linked to the old regime. These results highlight the complex long-run impact of arrest under autocracy. Notably, individuals who faced repression under autocracy do not participate at higher rates once the repressive regime has been removed, but their friends and family do. Finally, we conclude by outlining a new survey designed to give us better analytic leverage on this question and lay out a broader project on how the different socialization processes in authoritarian regimes affect political attitudes and behaviors after democratization.

\section{Repression and Political Socialization}

How does repression shape downstream political behavior? There is extensive research on the repression-backlash nexus focused on the relationship between repression and responses to repression in the short term (Davenport, 2007; Davenport and Inman, 2012; Sullivan and Davenport, 2017; Young, 2019; Pan and Siegel, 2020; Esberg, 2019). This work has produced mixed results. Sullivan and Davenport (2017) find that activists who personally experienced state repression subsequently challenge the government more, while those who did not experience direct repression withdrew from the political organization they had been active within. Conversely, Pan and Siegel (2020) show that Saudi Arabia's online opinion 
leaders reduce their online dissent after arrest; however, their online followers increase their dissent.

In the last several years, researchers have also begun to explore the long-run legacies of state repression (Balcells, 2011; Rozenas et al., 2017; Lupu and Peisakhin, 2017; Blaydes, 2018; Rozenas and Zhukov, 2019). Rozenas et al. (2017) and Lupu and Peisakhin (2017) both find that Ukrainian communities more exposed to violence at the hands of the Soviet state are less likely to support pro-Russian political forces and more likely to express hostility toward Russia today. Repression does not just increase the likelihood that victims and their communities turn against the perpetrators but can strengthen group identities, such as those connected to ethno-linguistic or religious communities. In her study of Iraq, Blaydes (2018) argues that collective punishment can reinforce communal identities through increased ingroup policing and reinforcing the group's sense of "linked fate."

Much of the work on the long-run effects of state repression has focused on the impact of political violence and forms of collective punishment rather than arrests. Arrests, however, represent one of the most ubiquitous forms of state repression. In this paper, we are interested in the how experiences with repression at the individual-level, specifically arrest, impact political participation and partisanship. Work on the effect of arrest in the United States suggests that even short stints in prison can decrease the likelihood that a voter casts her ballot in the next election by several percentage points (Weaver and Lerman, 2010; White, 2019b), while work on repression in autocratic regimes suggests that experience with repression may mobilize victims after the authoritarian threat is gone. Moreover, in light of evidence that the effect of arrest can be heterogeneous across those directly and indirectly affected, it is important to disentangle the direct effects of arrest from more indirect effects of arrest, such as how experiences with repression become part of family or community's political narrative.

Research on arrest and repression identifies several potential mechanisms through which 
repression, or specifically arrest, can have a demobilizational effect. First, arrest can have economic and employment consequences that continue even after an autocrat has left office. In Tunisia, even short jail stints become part of one's public record, even today. For admission into public universities and to apply for most jobs, applicants are required to provide a letter from the Ministry of Interior that summarizes their criminal history. Individuals arrested during the Ben Ali may still have less access to resources today compared with others who did not face arrest. Second, arrest, particularly of rank-and-file members of the political opposition or individuals who engage in only sporadic protest, may lead to reduced trust in political institutions or to less engagement in politics. This diminished trust or interest in politics may continue even after the political regime has changed.

The evidence on family and friends of incarcerated individuals is more mixed. Walker (2014) finds that individuals who have proximate rather than direct contact with the carceral state are more likely to vote and participate in politics. White (2019a), however, finds that household members of an individual convicted or incarcerated experience a small decrease in their likelihood of voting, but the effect is very short term. The indirect impact of arrest on family and friends can operate through family socialization. Family members may share information about a repressive experience or develop their own sense of "linked fate" within their family or community (Lupu and Peisakhin, 2017; Blaydes, 2018; Rozenas and Zhukov, 2019). In the Tunisian context, given the often political nature of arrests, the family and friends of an arrested individual may become politicized through hearing about the arrest and incarceration or through their own increased interactions with the government as a result. Conversely, household members of an incarcerated individual may also share in the arrestee's loss of resources and in her diminished trust or engagement in politics.

Thus, in this exploratory analysis and our proposed future research, we consider several possible effects of arrest on political behavior after a transition to democracy. Given the mixed results on political participation, we examine whether: 
- Direct repression increases [decreases] political participation

- The family and friends of a repressed individual are more [less] likely to participate in politics.

With regard to which candidate or party will be preferred when a previously arrested individual or her family and friends turn out to vote, most of the existing research suggests that people who experienced repression at the hand of the state are likely to oppose political actors who are linked to the perpetrators, especially once the threat of retribution has disappeared (Rozenas and Zhukov, 2019). Accordingly, regarding partisanship, we examine whether:

- Direct repression increases opposition to political actors associated with the perpetrators.

- The family and friends of a repressed individual are more likely to oppose political actors associated with the perpetrators.

Finally, we are interested in how the relationship between repression and political behavior are mediated through personal relationships. We expect that any correlation between knowing someone who was arrested and political participation or partisanship will be stronger the closer the personal relationship is. Thus, we expect that the correlation to be stronger for family members than for neighbors or community members.

\section{Arrests and Political Repression in Tunisia}

As the French negotiated their exit from Tunisia with Habib Bourguiba in 1955, Bourguiba, his supporters, and the French Administration had already began a campaign of repression against their political rivals. After Independence, the Bourguiba regime attempted to capture 
and eliminate all supporters of the pan-Islamic leader Salah Ben Youssef; some were jailed, some killed, and many were forced into exile (Perkins, 2014; Wolf, 2017). Ben Youssef was ultimately assassinated in Germany in 1961.

The Bourguiba regime continued to arrest political opponents, including both leftist and Islamist political forces depending on which posed a greater threat to Bourguiba's power at the time (Charrad, 1997; Perkins, 2014). Bourguiba's increasingly hard stance toward any political opposition, particularly the country's main Islamist movement, contributed to his ultimate removal from office. Zine el-Abidine Ben Ali, then the country's prime minister, ousted Bourguiba in a coup in 1987, in part as a result of mounting domestic and international opposition to the arrests of and death sentences handed down for several leaders of the the Islamic Tendency Movement (Mouvement de la Tendance Islamique, MTI).

Initially, Ben Ali signalled that he wanted to reverse course on the state's repression of its political opponents. In 1988, several political parties and movements negotiated the National Pact, a document many understood as an indication of Ben Ali's commitment to political pluralism (Anderson, 1991). Tunisia held multiparty legislative elections in 1989, and opposition parties were permitted to participate (albeit as independent candidates in the case of the MTI, recently renamed Ennahda Movement). Soon after the 1989 elections, however, the Ben Ali regime cracked down on opposition activists, beginning with the Islamists. $^{2}$ Several leaders of Ennahda were arrested, tortured, and handed significant jail sentences. Quickly, the Ben Ali regime expanded its repression to the rank-and-file supporters of Ennahda. Nugent (2020a) reports that, between 1990 and 1992, 8,000-10,000 Ennahda members were arrested and charged with crimes related to their political activities. Many of Tunisia's leftist political groups faced similar repression at the hand of the state. For instance, members of the Tunisian Workers' Communist Party (Parti communiste des

\footnotetext{
${ }^{2}$ The strength of the coercive apparatus in many Middle East and North African states and its potential for preventing democratization are well documented (Bellin, 2004).
} 
ouvriers de Tunisie, PCOT), including its leader Hamma Hammami, faced repeated arrests and prison sentences (Nugent, 2020a,b).

Beyond direct repression of political organizations and activists, the Ben Ali regime also employed the coercive apparatus of the state against less overtly political threats. Ben Ali maintained tight control of all religious activity in the country by stationing police in mosques and monitoring, if not scripting explicitly, the Friday sermons given each week (Rédaction RTBF, 2011). When asked about the logic of arrests under Ben Ali, survey respondents point to religious and political explanations for most arrests (Figure 1). Nearly 30 percent of respondents believe that the main reason for arrests under Ben Ali was to punish religious behavior, while nearly 20 percent believe people were arrested for their opposition to the regime. While we are unable to validate the reasons for arrest during those years, those explanations broadly accord with historical accounts of policing in that period. 
Figure 1: Reasons for Arrest

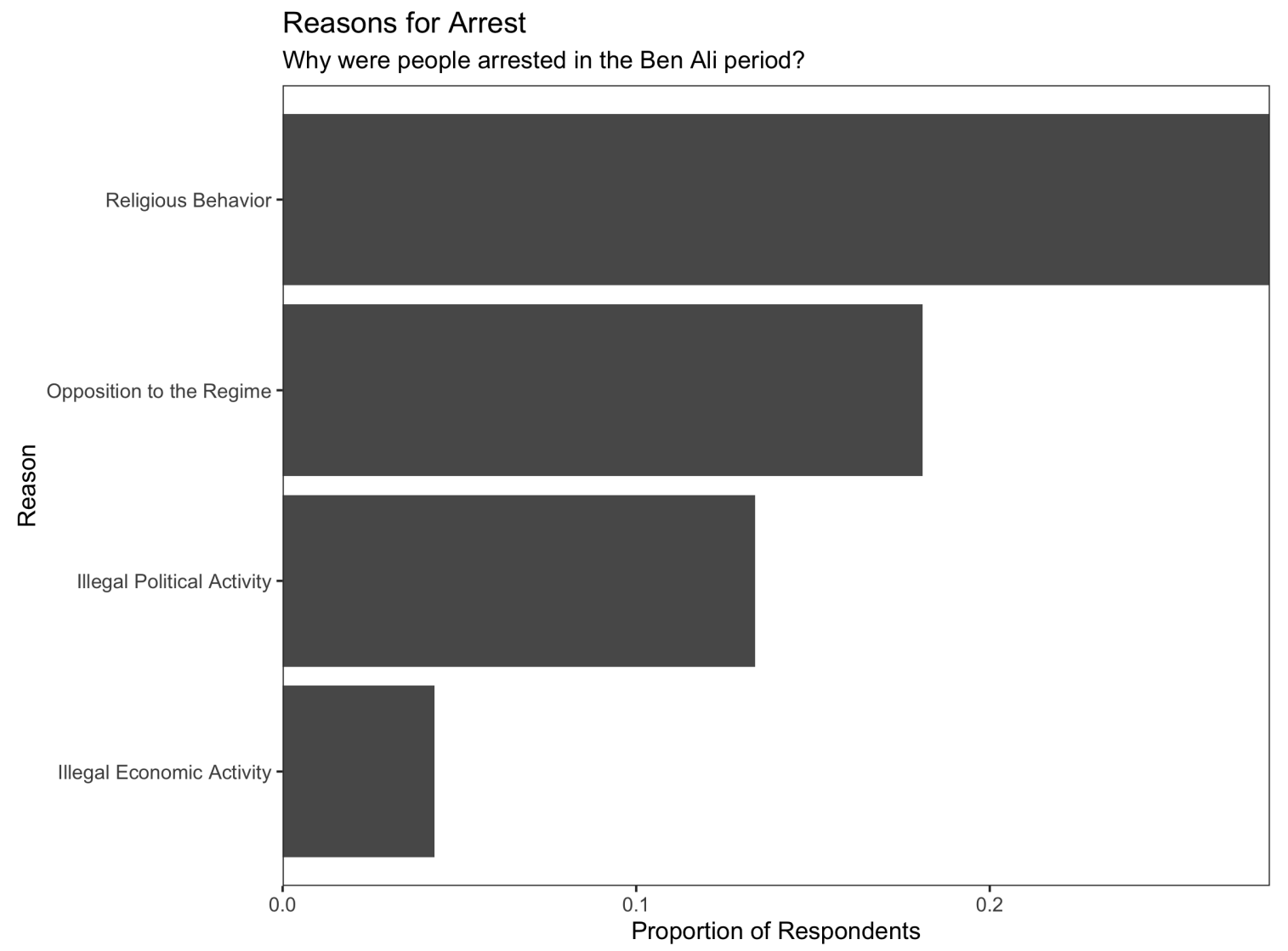

Additionally, Tunisia's rapidly growing prison population was not only comprised of political dissidents or religious activists. The increase in incarcerated individuals can also be traced back to the expansion of Tunisia's War on Drugs in 1992. That year, Ben Ali enacted law no. 92-52 (known as Law 52), which strengthened the criminalization of the use and sale of narcotics in the country and imposed harsh mandatory prison sentences for violations of the law (Advocats Sans Frontières, 2015; Guellali, 2016). There have been accusations that Law 52 was employed to target individuals who could pose a threat to the state, including primarily young men from marginalized backgrounds, but there is not direct evidence that it was used against members of the political opposition.

Our current survey data only give us information on whether the respondent was arrested during the Ben Ali period and whether the respondent knows anyone who was arrested at 
that time. In our proposed survey, we will extend this data collection by asking people specifically why they were arrested. In addition, our current survey provides us only with information on arrests. We know, however, that both the Bourguiba and Ben Ali regimes employed a variety of repressive tactics to intimidate or punish their opponents. In the upcoming survey, we expand the types of repression we will collect information on to include: economic punishment, house arrest, arrest, torture, exile, and forced disappearance. ${ }^{3}$ This proposed data collection will give us a better sense of how arrest compares to other forms of repression exercised in that period.

\section{Empirical Strategy}

In order to examine the relationship between arrests and subsequent political behavior, we use a nationally representative survey of 3000 Tunisians. The survey was fielded by One-toOne Polling in October and November 2017 and includes a battery of questions on arrests under Ben Ali. Respondents are asked if they personally were ever arrested during the Ben Ali regime, if they know anyone who was arrested under Ben Ali, how many people they know who were arrested, and what relationships they have to any of the individuals they know who were arrested. In our sample, 7.6 percent of respondents report being arrested under Ben Ali and 33 percent report knowing at least one person who was arrested under Ben Ali. ${ }^{4}$ Figure 2 displays the relationships respondents have with individuals arrested.

\footnotetext{
${ }^{3}$ We hope to be able to use this data to further distinguish between the use and effects of different types of repression as Davenport (2007) suggests.

${ }^{4}$ Women are about 8 percentage points less likely to report that they were arrested and and 17 percentage points less likely to report knowing people who were arrested. Both those arrested and those who know people who were arrested are more likely to be in the labor force (employed or unemployed). People who were arrested are also approximately 12 percentage points more likely to know others who were arrested.
} 
Figure 2: Relationship to Individual Arrested

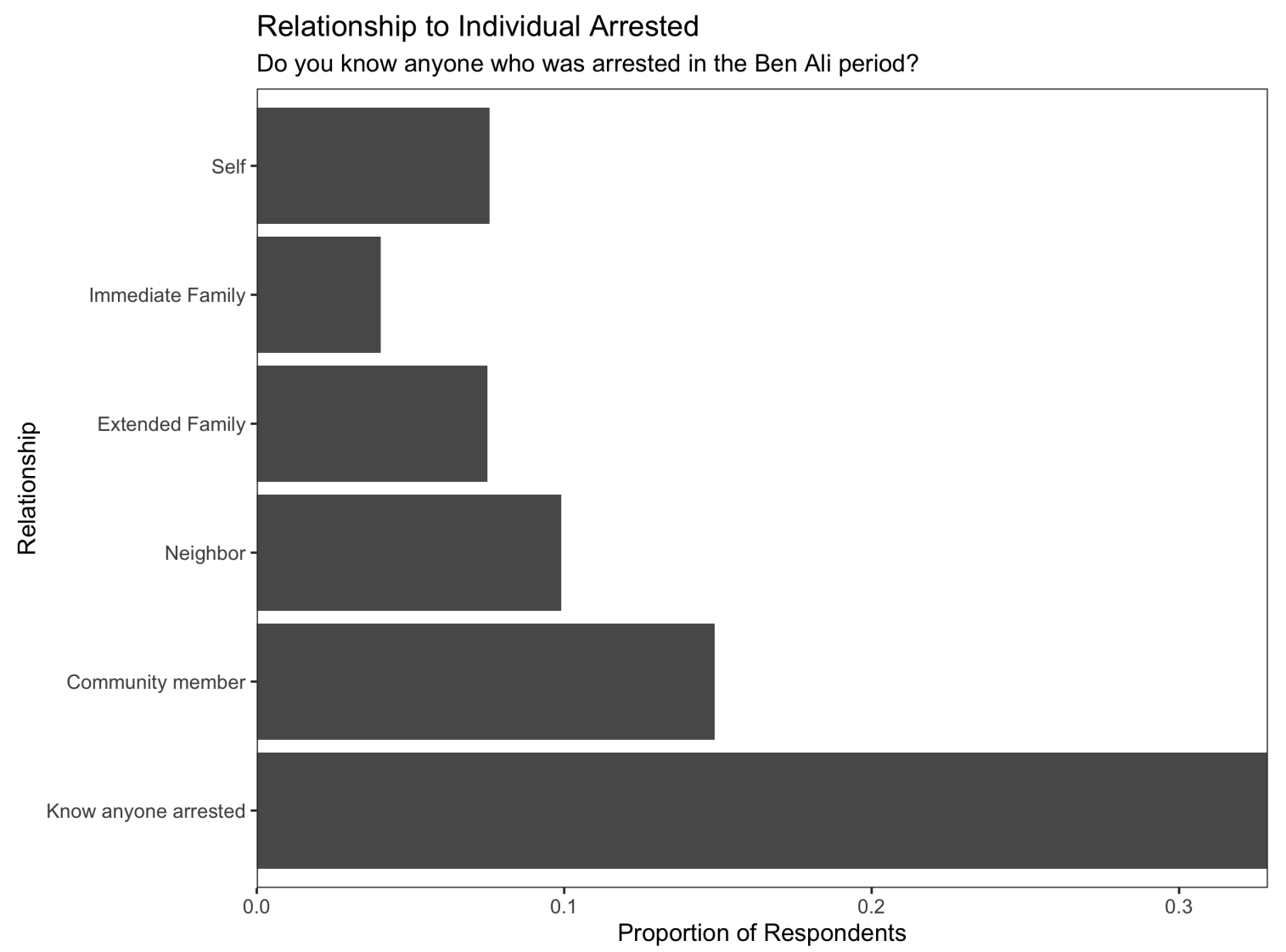

In addition to data on arrests under Ben Ali, we collect data on whether the respondent is registered to vote, whether they voted in the 2014 parliamentary and presidential elections, and which party or candidate they voted for in those elections. We use voter turnout as our primary measure of political participation. For partisanship, we are interested in whether repression is negatively associated with support for candidates and parties perceived as close to Tunisia's autocratic regimes. Thus we construct a binary measure for whether the respondent reported voting for the "old regime" party, Nidaa Tounes, or voted for the leader of Nidaa Tounes, Beji Caïd Essebsi, in the presidential contest. Essebsi, who was close to Bourguiba, held a variety of posts in the Tunisian government, including Minister of Defense and Minister of Foreign Affairs. Though more closely linked to Bourguiba than Ben Ali, Essebsi and Nidaa Tounes were viewed as close to the old regime, with some of 
its prominent members serving as government or business leaders during the Bourguiba and Ben Ali years.

We estimate the relationship between arrests and political participation and partisanship using a logit model. We examine four binary outcomes: (1) whether the respondent voted in the 2014 parlimentary elections; (2) whether the respondent voted in the 2014 presidential elections; (3) whether the respondent voted for the "old regime" party in 2014; and (4) whether the respondent voted for the "old regime" candidate in the presidential election in 2014. We estimate the following model, where $X_{i}$ is the respondent's personal history of arrest under the Ben Ali regime, $Z_{i}$ is whether the respondent knows anyone who was arrested during the Ben Ali regime, and $C_{i}$ is a vector of individual-level controls, and $\mathrm{g}$ is a vector of governorate fixed effects:

\section{PoliticalParticipation $/$ Partisanship $i=\alpha+\beta \mathbf{X}_{\mathbf{i}} * \beta \mathbf{Z}_{\mathbf{i}}+\beta C_{i}+\gamma_{g}+\epsilon$}

Standard errors are clustered at the delegation level $(\mathrm{n}=217)$ to address the possibility of correlated error terms within clusters. In this initial examination, we control for several individual-level characteristics, including gender, age, education level, employment status, marital status, and economic status. OLS results and results for whether the respondent is registered to vote are included in the Supplementary Appendix (Tables A.2 - A.6).

In this preliminary analysis, we focus on how a history of arrest is correlated with current political participation and partisanship, while controlling for other relevant individual characteristics, such as gender, age, education, employment, and socio-economic status. In the final section of this paper, we discuss how we can improve this research design in future survey work, including an original survey of the political attitudes and behaviors of siblings. In addition, we identify several quantities of interest that we argue will give us better analytic leverage on the relationship between repression, political socialization, and political 
participation after democratization.

\section{Results}

Using the approach outlined above, we provide preliminary evidence that arrests under autocracy do not lead to greater political participation after democratization for those arrested under Ben Ali but do lead to greater participation for those whose family members were arrested under Ben Ali. We find that individuals who report knowing someone arrested are approximately ten percentage points more likely to have voted in the 2014 parliamentary elections and six percentage points more likely to have voted in the 2014 presidential elections. We present the overall predicted probabilities in Figure 3 and the OLS results in Tables A.3 and A.4 in the Appendix.

When we look at the results by the relationship to the person arrested, we find that the positive correlation between knowing someone arrested and voting is strongest for those individuals who report having a family member who was arrested. This is broadly consistent with our hypotheses that the relationship between knowing someone who faced arrest under Ben Ali is stronger the closer those individuals are to the respondent. 
Figure 3: Arrests and Political Participation
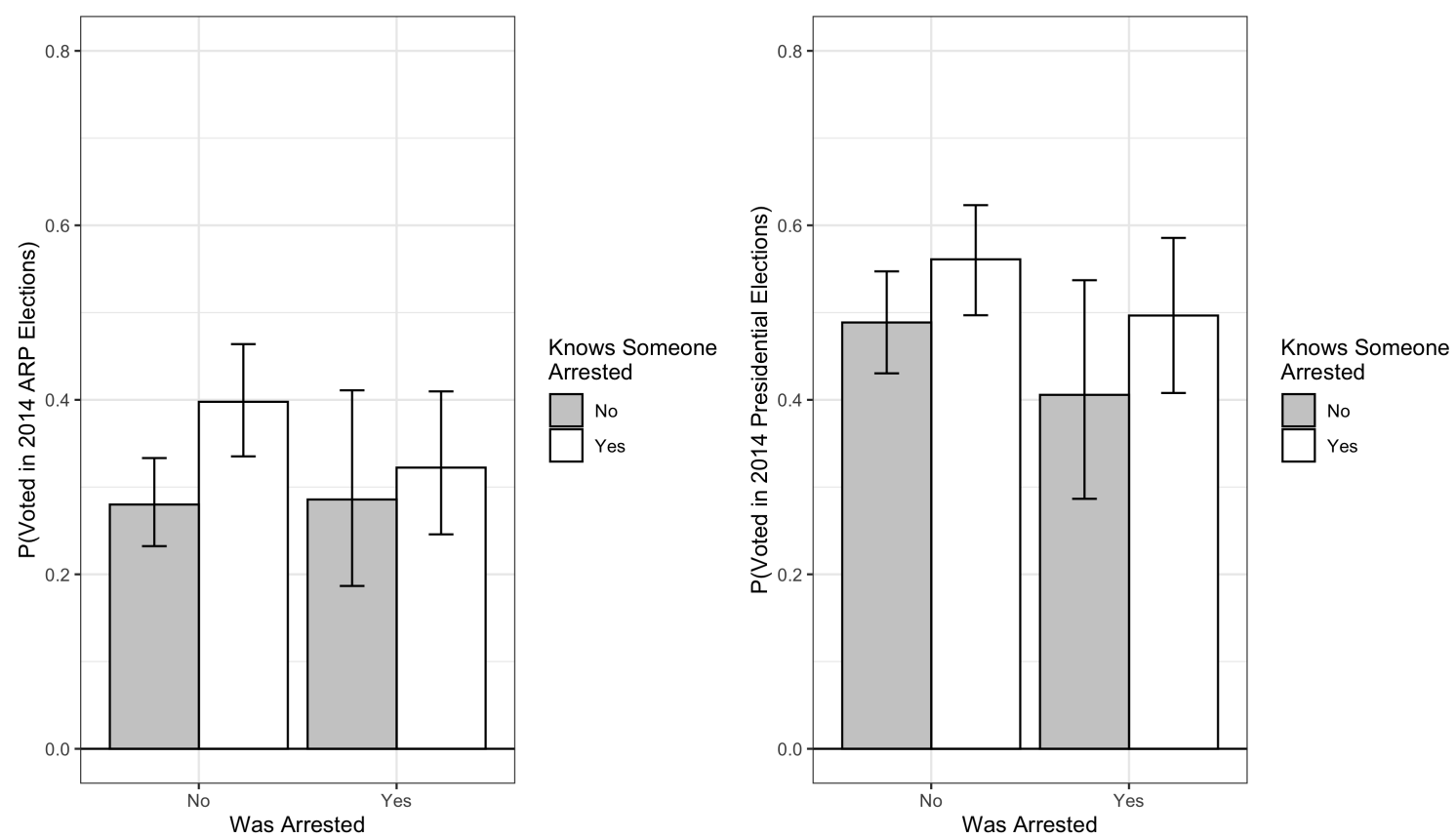

In the case of partisanship, we find that both individuals who experienced arrest and those who reported knowing individuals who were arrested are less likely to support the "old regime" party and presidential candidate. In the parliamentary elections, both former arrestees and people in their networks were over 10 percentage points less likely to vote for Nidaa Tounes. During the presidential run-off election between Essebsi and Moncef Marzouki, a human rights activist endorsed by the main Islamist party, former arrestees and people in their networks were roughly 15 percentage points less likely to support Essebsi. Figure 4 displays the predicted probabilities and Tables A.5 and A.6 display the OLS results. 
Figure 4: Arrests and Partisanship
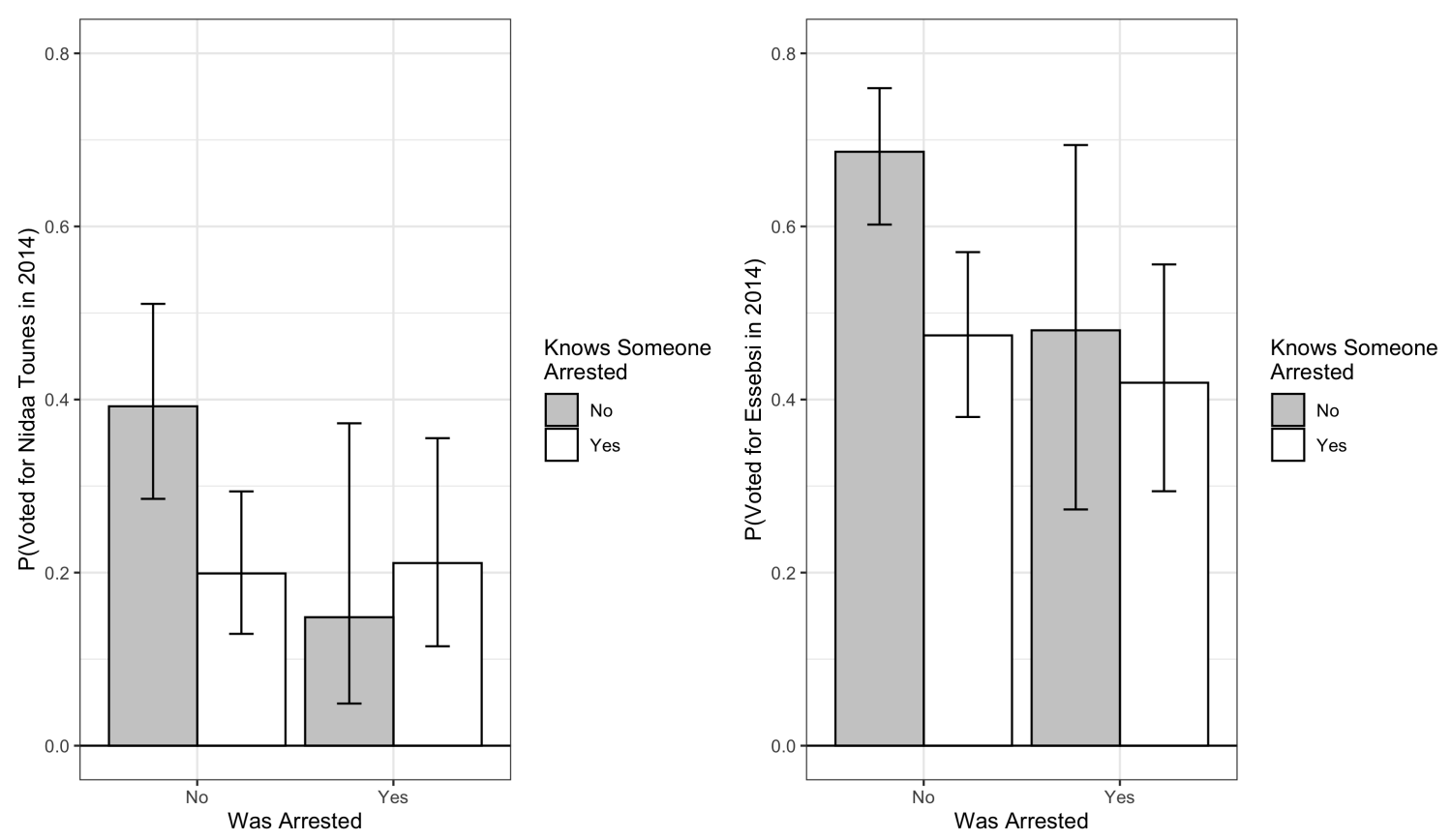

Looking closer at the relationship between who is arrested and partisanship, the closeness of the person arrested (e.g., family member versus community member) does not appear to mediate the relationship as expected. The negative correlation between knowing someone who was arrested and support for "old regime" political actors is, in fact, weakest when the arrested person is a family member. We need to do more work to understand how personal relationships mediate the relationship between arrests and political behavior.

\section{Looking Ahead}

In this paper, we have identified several ways in which arrest under autocracy can affect political participation and partisanship. The mobilizational effects of repression are heterogeneous within families; examining arrests at the individual-level, we find that arrests appear to mobilize those who have a family member who experienced arrest, but not the arrestees themselves. The partisan effects of repression, however, appear to be shared. Both those 
who faced arrest or who know individuals arrested are less likely to support the old regime candidates and party. ${ }^{5}$

In this section, we propose an original survey for gaining additional analytic leverage on the question of family socialization and past experiences with repression. We will field the proposed survey in mid-March in Tunisia. There are several threats to inference in the current approach that we seek to address in this new survey. One of the primary threats to inference is the possibility that the regime targeted political activists for arrest. While it is clear that Tunisia's authoritarian regime was occasionally fairly indiscriminate in its approach to arrests, it is likely that the regime also directed its repression against certain political opponents. A second challenge is trying to validate some of the arrest reports. While we cannot get access to data from the Ministry of Interior on arrest records, we can ask family members of our primary respondents to validate some of the personal and family histories with state repression.

We identify three relevant comparison groups that we argue will allow us to move beyond the preliminary findings presented above and help us to address these threats to inference. First, we will compare the current political attitudes and behaviors of arrested political activists, non-arrested political activists, and political activists who have family members who were arrested. In the proposed survey, we collect data on political activism during the authoritarian period. This enables us to focus on the impact of arrests specifically, even among political activists.

Second, our proposed survey will allow us to compare the current political attitudes and behaviors of those arrested during the authoritarian period for political and non-political reasons. In the proposed survey, we ask respondents for additional details on the reason for their arrest. As discussed above, many were arrested for political or religious reasons; how-

\footnotetext{
${ }^{5}$ In the Middle East and North Africa, further research is needed to understand preferences for these authoritarian successor parties (Grzymala-Busse, 2020). Some recent research in Tunisia examines how the voter-party linkages in autocracies can vary by region (Berman and Nugent, 2019).
} 
ever, particularly during the Ben Ali regime, the Tunisian carceral state expanded markedly as a result of the global War on Drugs and the criminalization of certain economic behaviors. Additional details on the reasons for the arrest will allow us to contrast those who were arrested or know people arrested for political versus non-political activities.

Third, in addition to a nationally representative survey, we will run a secondary survey of 500 of our primary respondents' siblings. We will collect sibling information at the outset of the interview and randomly select a sibling to interview. The secondary survey asks the same questions about family history, political attitudes and behaviors, and school socialization. Using this survey, we can compare individuals who were arrested or who know individuals who were arrested under the previous regime (as well as faced other forms of repression) with their siblings. This allows us to better control for other aspects of political socialization in autocracies, in particular other aspects of family socialization, and to validate some of the responses on personal and family experiences under autocracy.

\section{References}

Achen, C. H. (2002). Parental Socialization and Rational Party Identification. Political Behavior, 24(2):151-170.

Advocats Sans Frontières (2015). Detention in Tunisia: Sanctions that go beyond deprivation of liberty. Technical report, Advocats Sans Frontières.

Anderson, L. (1991). Political Pacts, Liberalism, and Democracy: The Tunisian National Pact of 1988. Government and Opposition, 26(2):244-260.

Balcells, L. (2011). The Consequences of Victimization on Political Identities: Evidence from Spain. Politics \& Society, 40(3):311-347.

Bellin, E. (2004). The Robustness of Authoritarianism in the Middle East: Exceptionalism in Comparative Perspective. Comparative Politics, 36(2):139-157.

Bengtson, V. L. (1975). Generation and Family Effects in Value Socialization. American Sociological Review, 40(3):358-371.

Berman, C. E. and Nugent, E. R. (2019). Regionalism in New Democracies: The Authoritarian Origins of Voter-Party Linkages. Political Research Quarterly. 
Blaydes, L. (2018). State of Repression: Iraq under Saddam Hussein. Princeton University Press, New Jersey.

Charrad, M. M. (1997). Policy Shifts: State, Islam, and Gender in Tunisia, 1930s-1990s. Social Politics: International Studies in Gender, State 6 Society, 4(2):284-319.

Davenport, C. (2007). State Repression and Political Order. Annual Review of Political Science, 10(1):1-23.

Davenport, C. and Inman, M. (2012). The State of State Repression Research Since the 1990s. Terrorism and Political Violence, 24(4):619-634.

Esberg, J. (2019). The Audience of Repression: Killings and Disappearances in Pinochet's Chile. Working Paper.

Grzymala-Busse, A. (2020). Consequences of Authoritarian Party Exit and Reinvention for Democratic Competition. Comparative Political Studies.

Guellali, A. (2016). All this for a Joint: Tunisia's Repressive Drug Law and a Roadmap for Its Reform. Technical report, Human Rights Watch.

Jennings, M. K., Stoker, L., and Bowers, J. (2009). Politics across Generations: Family Transmission Reexamined. The Journal of Politics, 71(3):782-799.

Lupu, N. and Peisakhin, L. (2017). The Legacy of Political Violence across Generations. American Journal of Political Science, 61(4):836-851.

Nugent, E. R. (2020a). After Repression: How Polarization Derails Democratic Transition. Princeton University Press, New Jersey.

Nugent, E. R. (2020b). The Psychology of Repression and Polarization. World Politics, $72(2)$.

Pan, J. and Siegel, A. A. (2020). How Saudi Crackdowns Fail to Silence Online Dissent. American Political Science Review, 114(1):109-125.

Perkins, K. (2014). A History of Modern Tunisia. Cambridge University Press, Cambridge, 2 edition.

Pop-Eleches, G. and Tucker, J. A. (2019). Communist Legacies and Left-Authoritarianism. Comparative Political Studies.

Rédaction RTBF (2011). Tunisie: le nom de Ben Ali biffé des sermons des imams.

Rozenas, A., Schutte, S., and Zhukov, Y. (2017). The Political Legacy of Violence: The Long-Term Impact of Stalin's Repression in Ukraine. The Journal of Politics, 79(4):11471161. 
Rozenas, A. and Zhukov, Y. M. (2019). Mass repression and political loyalty: Evidence from Stalin's 'terror by hunger'. American Political Science Review, 113(2):569-583.

Sullivan, C. M. and Davenport, C. (2017). The Rebel Alliance Strikes Back: Understanding the Politics of Backlash Mobilization. Mobilization: An International Quarterly, 22(1):3956.

Ventura, R. (2001). Family Political Socialization in Multiparty Systems. Comparative Political Studies, 34(6):666-691.

Walker, H. L. (2014). Extending the Effects of the Carceral State: Proximal Contact, Political Participation, and Race. Political Research Quarterly, 67(4):809-822.

Weaver, V. M. and Lerman, A. E. (2010). Political consequences of the carceral state. American Political Science Review, 104(4):817-833.

White, A. (2019a). Family Matters? Voting Behavior in Households with Criminal Justice Contact. American Political Science Review, 113(2):607-613.

White, A. (2019b). Misdemeanor Disenfranchisement? The Demobilizing Effects of Brief Jail Spells on Potential Voters. American Political Science Review, 113(2):311-324.

Wolf, A. (2017). Political Islam in Tunisia: A History of Ennahda. Oxford University Press, Oxford.

Young, L. E. (2019). The Psychology of State Repression: Fear and Dissent Decisions in Zimbabwe. American Political Science Review, 113(1):140-155. 


\section{Supplementary Appendix: Political Socialization in New Democracies: Legacies of Repression and Pre-Democratic Partisanship}

\section{Contents}

1 Results: Voter Registration $\quad 2$

2 Results: Voter Turnout 4

3 Results: Vote Choice $\quad 6$

4 Proposed Survey: Sample of Survey Instrument on Repression and Family Legacies 


\section{Results: Voter Registration}

Figure A.1: Arrests and Registration

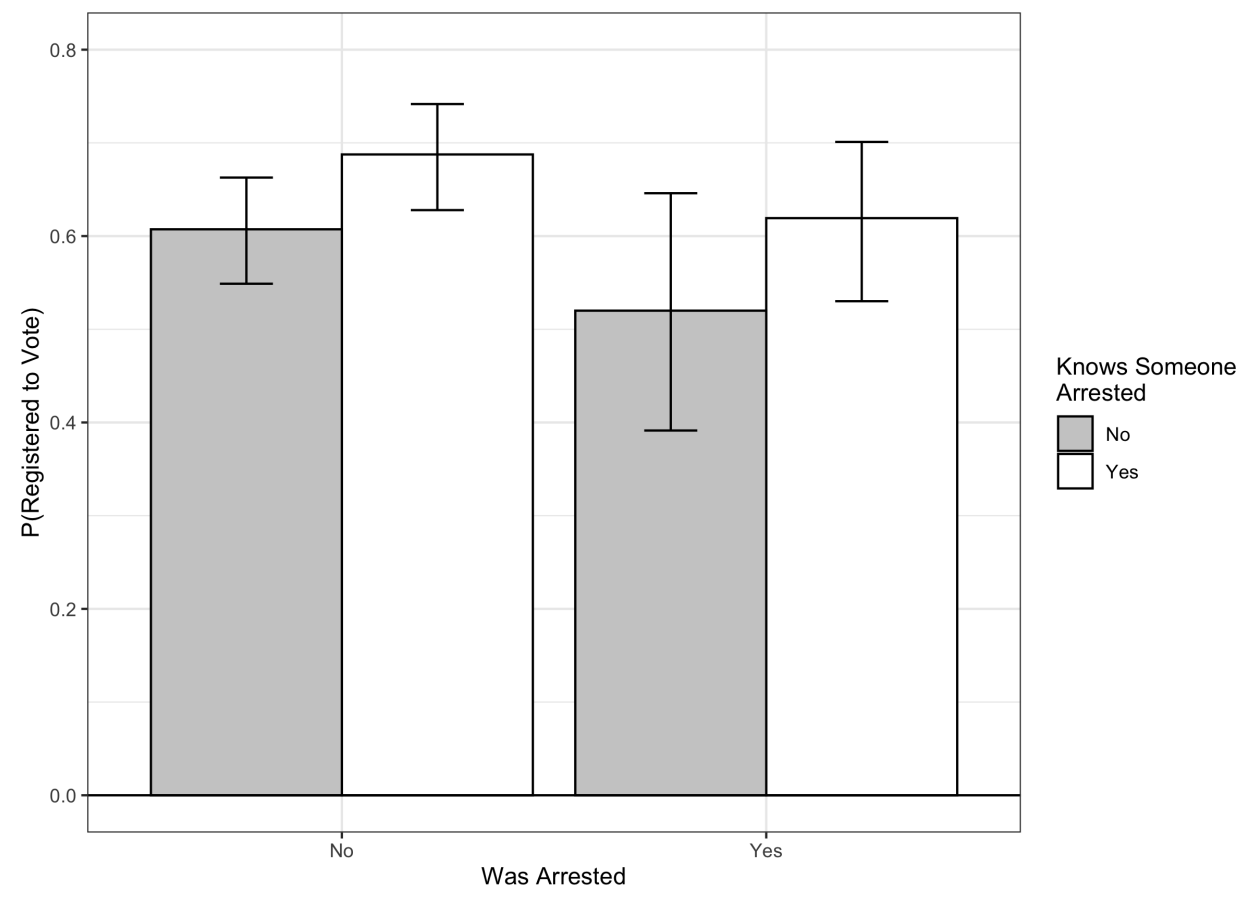

Note: $90 \%$ confidence intervals. 
Table A.2: Correlates of Voter Registration

\begin{tabular}{|c|c|c|c|c|c|c|}
\hline & \multicolumn{6}{|c|}{ Dependent variable: } \\
\hline & \multicolumn{6}{|c|}{ Registered } \\
\hline & (1) & $(2)$ & $(3)$ & (4) & $(5)$ & (6) \\
\hline Arrested & $\begin{array}{l}-0.035 \\
(0.032)\end{array}$ & & $\begin{array}{l}-0.035 \\
(0.033)\end{array}$ & & & $\begin{array}{l}-0.071 \\
(0.070)\end{array}$ \\
\hline Knows Someone Arrested & & $\begin{array}{c}0.090^{* * *} \\
(0.018)\end{array}$ & & $\begin{array}{c}0.062^{* * *} \\
(0.017)\end{array}$ & & $\begin{array}{c}0.069^{* * *} \\
(0.018)\end{array}$ \\
\hline Arrested*Knows Someone Arrested & & & & & & $\begin{array}{c}0.013 \\
(0.082)\end{array}$ \\
\hline Family Member Arrested & & & & & $\begin{array}{c}0.020 \\
(0.024)\end{array}$ & \\
\hline Neighbors Arrested & & & & & $\begin{array}{l}0.044^{*} \\
(0.026)\end{array}$ & \\
\hline Community Member Arrested & & & & & $\begin{array}{c}0.070^{* * *} \\
(0.021)\end{array}$ & \\
\hline Female & $\begin{array}{c}-0.057^{* * *} \\
(0.018)\end{array}$ & $\begin{array}{c}-0.035^{* *} \\
(0.018)\end{array}$ & $\begin{array}{l}-0.025 \\
(0.019)\end{array}$ & $\begin{array}{l}-0.011 \\
(0.019)\end{array}$ & $\begin{array}{l}-0.011 \\
(0.019)\end{array}$ & $\begin{array}{l}-0.015 \\
(0.019)\end{array}$ \\
\hline Age & $\begin{array}{c}0.011^{* * *} \\
(0.0005)\end{array}$ & $\begin{array}{l}0.011^{* * *} \\
(0.0005)\end{array}$ & $\begin{array}{c}0.011^{* * *} \\
(0.001)\end{array}$ & $\begin{array}{c}0.011^{* * *} \\
(0.001)\end{array}$ & $\begin{array}{c}0.011^{* * *} \\
(0.001)\end{array}$ & $\begin{array}{c}0.011^{* * *} \\
(0.001)\end{array}$ \\
\hline Secondary+ Education & & & $\begin{array}{c}0.209^{* * *} \\
(0.021)\end{array}$ & $\begin{array}{c}0.202^{* * *} \\
(0.021)\end{array}$ & $\begin{array}{c}0.205^{* * *} \\
(0.020)\end{array}$ & $\begin{array}{c}0.200^{* * *} \\
(0.021)\end{array}$ \\
\hline Employed & & & $\begin{array}{c}0.111^{* * *} \\
(0.020)\end{array}$ & $\begin{array}{c}0.105^{* * *} \\
(0.020)\end{array}$ & $\begin{array}{c}0.105^{* * *} \\
(0.020)\end{array}$ & $\begin{array}{c}0.108^{* * *} \\
(0.020)\end{array}$ \\
\hline Unemployed & & & $\begin{array}{l}0.040^{*} \\
(0.024)\end{array}$ & $\begin{array}{c}0.035 \\
(0.024)\end{array}$ & $\begin{array}{c}0.034 \\
(0.024)\end{array}$ & $\begin{array}{c}0.038 \\
(0.024)\end{array}$ \\
\hline SES & & & $\begin{array}{l}-0.012 \\
(0.009)\end{array}$ & $\begin{array}{l}-0.012 \\
(0.009)\end{array}$ & $\begin{array}{l}-0.012 \\
(0.009)\end{array}$ & $\begin{array}{l}-0.011 \\
(0.009)\end{array}$ \\
\hline Married/Widowed & & & $\begin{array}{c}0.084^{* * *} \\
(0.026)\end{array}$ & $\begin{array}{c}0.085^{* * *} \\
(0.026)\end{array}$ & $\begin{array}{c}0.086^{* * *} \\
(0.026)\end{array}$ & $\begin{array}{c}0.086^{* * *} \\
(0.026)\end{array}$ \\
\hline Constant & $\begin{array}{c}0.134^{* *} \\
(0.053)\end{array}$ & $\begin{array}{c}0.091 \\
(0.057)\end{array}$ & $\begin{array}{c}0.006 \\
(0.065)\end{array}$ & $\begin{array}{l}-0.017 \\
(0.068)\end{array}$ & $\begin{array}{l}-0.016 \\
(0.068)\end{array}$ & $\begin{array}{l}-0.017 \\
(0.067)\end{array}$ \\
\hline Governorate FEs & Yes & Yes & Yes & Yes & Yes & Yes \\
\hline Observations & 2,963 & 2,960 & 2,943 & 2,940 & 2,947 & 2,937 \\
\hline Adjusted $\mathrm{R}^{2}$ & 0.120 & 0.127 & 0.168 & 0.171 & 0.171 & 0.172 \\
\hline
\end{tabular}




\section{Results: Voter Turnout}

\section{Parliamentary Elections}

Table A.3: Correlates of Voter Turnout

\begin{tabular}{|c|c|c|c|c|c|c|}
\hline & \multicolumn{6}{|c|}{ Dependent variable: } \\
\hline & \multicolumn{6}{|c|}{ Voted in 2014 Parliamentary Election } \\
\hline & $(1)$ & $(2)$ & (3) & (4) & $(5)$ & $(6)$ \\
\hline Arrested & $\begin{array}{l}-0.020 \\
(0.030)\end{array}$ & & $\begin{array}{l}-0.014 \\
(0.029)\end{array}$ & & & $\begin{array}{l}-0.003 \\
(0.059)\end{array}$ \\
\hline Knows Someone Arrested & & $\begin{array}{c}0.124^{* * *} \\
(0.019)\end{array}$ & & $\begin{array}{c}0.090^{* * *} \\
(0.018)\end{array}$ & & $\begin{array}{c}0.101^{* * *} \\
(0.019)\end{array}$ \\
\hline Arrested*Knows Someone Arrested & & & & & & $\begin{array}{l}-0.066 \\
(0.071)\end{array}$ \\
\hline Family Member Arrested & & & & & $\begin{array}{c}0.096^{* * *} \\
(0.027)\end{array}$ & \\
\hline Neighbors Arrested & & & & & $\begin{array}{c}0.061^{* *} \\
(0.028)\end{array}$ & \\
\hline Community Member Arrested & & & & & $\begin{array}{c}0.054^{* *} \\
(0.024)\end{array}$ & \\
\hline Female & $\begin{array}{c}-0.146^{* * *} \\
(0.017)\end{array}$ & $\begin{array}{c}-0.118^{* * *} \\
(0.018)\end{array}$ & $\begin{array}{c}-0.113^{* * *} \\
(0.021)\end{array}$ & $\begin{array}{c}-0.096^{* * *} \\
(0.021)\end{array}$ & $\begin{array}{c}-0.103^{* * *} \\
(0.021)\end{array}$ & $\begin{array}{c}-0.098^{* * *} \\
(0.021)\end{array}$ \\
\hline Age & $\begin{array}{c}0.008^{* * *} \\
(0.001)\end{array}$ & $\begin{array}{c}0.008^{* * *} \\
(0.001)\end{array}$ & $\begin{array}{c}0.009^{* * *} \\
(0.001)\end{array}$ & $\begin{array}{c}0.009^{* * *} \\
(0.001)\end{array}$ & $\begin{array}{c}0.009^{* * *} \\
(0.001)\end{array}$ & $\begin{array}{c}0.009^{* * *} \\
(0.001)\end{array}$ \\
\hline Secondary + Education & & & $\begin{array}{c}0.254^{* * *} \\
(0.022)\end{array}$ & $\begin{array}{c}0.243^{* * *} \\
(0.022)\end{array}$ & $\begin{array}{c}0.245^{* * *} \\
(0.022)\end{array}$ & $\begin{array}{c}0.242^{* * *} \\
(0.022)\end{array}$ \\
\hline Employed & & & $\begin{array}{c}0.100^{* * *} \\
(0.020)\end{array}$ & $\begin{array}{c}0.092^{* * *} \\
(0.020)\end{array}$ & $\begin{array}{c}0.093^{* * *} \\
(0.020)\end{array}$ & $\begin{array}{c}0.096^{* * *} \\
(0.020)\end{array}$ \\
\hline Unemployed & & & $\begin{array}{l}0.041^{*} \\
(0.023)\end{array}$ & $\begin{array}{c}0.034 \\
(0.023)\end{array}$ & $\begin{array}{c}0.035 \\
(0.023)\end{array}$ & $\begin{array}{c}0.037 \\
(0.023)\end{array}$ \\
\hline SES & & & $\begin{array}{c}-0.030^{* * *} \\
(0.010)\end{array}$ & $\begin{array}{c}-0.028^{* * *} \\
(0.010)\end{array}$ & $\begin{array}{c}-0.029^{* * *} \\
(0.010)\end{array}$ & $\begin{array}{c}-0.028^{* * *} \\
(0.010)\end{array}$ \\
\hline Married/Widowed & & & $\begin{array}{c}0.080^{* * *} \\
(0.025)\end{array}$ & $\begin{array}{c}0.081^{* * *} \\
(0.025)\end{array}$ & $\begin{array}{c}0.082^{* * *} \\
(0.025)\end{array}$ & $\begin{array}{c}0.080^{* * *} \\
(0.025)\end{array}$ \\
\hline Constant & $\begin{array}{c}0.068 \\
(0.066)\end{array}$ & $\begin{array}{c}0.014 \\
(0.071)\end{array}$ & $\begin{array}{l}-0.022 \\
(0.074)\end{array}$ & $\begin{array}{l}-0.054 \\
(0.078)\end{array}$ & $\begin{array}{l}-0.048 \\
(0.078)\end{array}$ & $\begin{array}{l}-0.055 \\
(0.077)\end{array}$ \\
\hline Governorate FEs & Yes & Yes & Yes & Yes & Yes & Yes \\
\hline Observations & 2,874 & 2,873 & 2,857 & 2,856 & 2,861 & 2,853 \\
\hline Adjusted $\mathrm{R}^{2}$ & 0.090 & 0.103 & 0.159 & 0.165 & 0.166 & 0.167 \\
\hline
\end{tabular}




\section{Presidential Elections - Runoff}

Table A.4: Correlates of Voter Turnout

\begin{tabular}{|c|c|c|c|c|c|c|}
\hline & \multicolumn{6}{|c|}{ Dependent variable: } \\
\hline & \multicolumn{6}{|c|}{ Voted in 2014 Presidential Election } \\
\hline & $(1)$ & $(2)$ & $(3)$ & $(4)$ & $(5)$ & $(6)$ \\
\hline Arrested & $\begin{array}{l}-0.045 \\
(0.031)\end{array}$ & & $\begin{array}{l}-0.039 \\
(0.032)\end{array}$ & & & $\begin{array}{l}-0.073 \\
(0.061)\end{array}$ \\
\hline Knows Someone Arrested & & $\begin{array}{c}0.082^{* * *} \\
(0.018)\end{array}$ & & $\begin{array}{c}0.054^{* * *} \\
(0.018)\end{array}$ & & $\begin{array}{c}0.061^{* * *} \\
(0.018)\end{array}$ \\
\hline Arrested*Knows Someone Arrested & & & & & & $\begin{array}{c}0.015 \\
(0.074)\end{array}$ \\
\hline Family Member Arrested & & & & & $\begin{array}{c}0.051^{* *} \\
(0.025)\end{array}$ & \\
\hline Neighbors Arrested & & & & & $\begin{array}{c}0.036 \\
(0.030)\end{array}$ & \\
\hline Community Member Arrested & & & & & $\begin{array}{c}0.040 \\
(0.025)\end{array}$ & \\
\hline Female & $\begin{array}{c}-0.062^{* * *} \\
(0.016)\end{array}$ & $\begin{array}{c}-0.041^{* *} \\
(0.017)\end{array}$ & $\begin{array}{l}-0.026 \\
(0.019)\end{array}$ & $\begin{array}{l}-0.014 \\
(0.019)\end{array}$ & $\begin{array}{l}-0.016 \\
(0.019)\end{array}$ & $\begin{array}{l}-0.017 \\
(0.019)\end{array}$ \\
\hline Age & $\begin{array}{c}0.012^{* * *} \\
(0.001)\end{array}$ & $\begin{array}{c}0.012^{* * *} \\
(0.001)\end{array}$ & $\begin{array}{c}0.013^{* * *} \\
(0.001)\end{array}$ & $\begin{array}{c}0.013^{* * *} \\
(0.001)\end{array}$ & $\begin{array}{c}0.013^{* * *} \\
(0.001)\end{array}$ & $\begin{array}{c}0.013^{* * *} \\
(0.001)\end{array}$ \\
\hline Secondary+ Education & & & $\begin{array}{c}0.216^{* * *} \\
(0.021)\end{array}$ & $\begin{array}{c}0.209^{* * *} \\
(0.021)\end{array}$ & $\begin{array}{c}0.212^{* * *} \\
(0.021)\end{array}$ & $\begin{array}{c}0.208^{* * *} \\
(0.022)\end{array}$ \\
\hline Employed & & & $\begin{array}{c}0.099^{* * *} \\
(0.022)\end{array}$ & $\begin{array}{c}0.093^{* * *} \\
(0.022)\end{array}$ & $\begin{array}{c}0.093^{* * *} \\
(0.022)\end{array}$ & $\begin{array}{c}0.096^{* * *} \\
(0.022)\end{array}$ \\
\hline Unemployed & & & $\begin{array}{c}0.018 \\
(0.024)\end{array}$ & $\begin{array}{c}0.012 \\
(0.024)\end{array}$ & $\begin{array}{c}0.012 \\
(0.024)\end{array}$ & $\begin{array}{c}0.016 \\
(0.024)\end{array}$ \\
\hline SES & & & $\begin{array}{l}-0.014 \\
(0.010)\end{array}$ & $\begin{array}{l}-0.014 \\
(0.010)\end{array}$ & $\begin{array}{l}-0.015 \\
(0.010)\end{array}$ & $\begin{array}{l}-0.013 \\
(0.010)\end{array}$ \\
\hline Married/Widowed & & & $\begin{array}{c}0.042 \\
(0.027)\end{array}$ & $\begin{array}{c}0.042 \\
(0.027)\end{array}$ & $\begin{array}{c}0.043 \\
(0.027)\end{array}$ & $\begin{array}{c}0.042 \\
(0.027)\end{array}$ \\
\hline Constant & $\begin{array}{c}0.017 \\
(0.068)\end{array}$ & $\begin{array}{l}-0.024 \\
(0.074)\end{array}$ & $\begin{array}{l}-0.085 \\
(0.079)\end{array}$ & $\begin{array}{l}-0.106 \\
(0.083)\end{array}$ & $\begin{array}{l}-0.104 \\
(0.082)\end{array}$ & $\begin{array}{l}-0.105 \\
(0.082)\end{array}$ \\
\hline Governorate FEs & Yes & Yes & Yes & Yes & Yes & Yes \\
\hline Observations & 2,963 & 2,960 & 2,943 & 2,940 & 2,947 & 2,937 \\
\hline Adjusted $\mathrm{R}^{2}$ & 0.134 & 0.140 & 0.177 & 0.180 & 0.179 & 0.180 \\
\hline
\end{tabular}




\section{Results: Vote Choice}

\section{Parliamentary Elections}

Table A.5: Correlates of Nidaa Voting

\begin{tabular}{|c|c|c|c|c|c|c|}
\hline & \multicolumn{6}{|c|}{ Dependent variable: } \\
\hline & & & Voted for & idaa (2014) & & \\
\hline & $(1)$ & $(2)$ & $(3)$ & $(4)$ & $(5)$ & $(6)$ \\
\hline Arrested & $\begin{array}{c}-0.108^{*} \\
(0.061)\end{array}$ & & $\begin{array}{c}-0.107^{*} \\
(0.062)\end{array}$ & & & $\begin{array}{c}-0.253^{* *} \\
(0.115)\end{array}$ \\
\hline Knows Someone Arrested & & $\begin{array}{c}-0.187^{* * *} \\
(0.036)\end{array}$ & & $\begin{array}{c}-0.180^{* * *} \\
(0.036)\end{array}$ & & $\begin{array}{c}-0.190^{* * *} \\
(0.038)\end{array}$ \\
\hline Arrested*Knows Someone Arrested & & & & & & $\begin{array}{c}0.262^{*} \\
(0.134)\end{array}$ \\
\hline Family Member Arrested & & & & & $\begin{array}{c}-0.080^{*} \\
(0.045)\end{array}$ & \\
\hline Neighbors Arrested & & & & & $\begin{array}{c}-0.128^{* * *} \\
(0.046)\end{array}$ & \\
\hline Community Member Arrested & & & & & $\begin{array}{c}-0.137^{* * *} \\
(0.042)\end{array}$ & \\
\hline Female & $\begin{array}{c}-0.059^{*} \\
(0.034)\end{array}$ & $\begin{array}{c}-0.083^{* *} \\
(0.035)\end{array}$ & $\begin{array}{l}-0.048 \\
(0.039)\end{array}$ & $\begin{array}{c}-0.064^{*} \\
(0.038)\end{array}$ & $\begin{array}{l}-0.060 \\
(0.038)\end{array}$ & $\begin{array}{c}-0.068^{*} \\
(0.039)\end{array}$ \\
\hline Age & $\begin{array}{c}0.007^{* * *} \\
(0.001)\end{array}$ & $\begin{array}{c}0.006^{* * *} \\
(0.001)\end{array}$ & $\begin{array}{c}0.007^{* * * *} \\
(0.002)\end{array}$ & $\begin{array}{c}0.008^{* * *} \\
(0.002)\end{array}$ & $\begin{array}{c}0.008^{* * *} \\
(0.002)\end{array}$ & $\begin{array}{c}0.008^{* * *} \\
(0.002)\end{array}$ \\
\hline Secondary + Education & & & $\begin{array}{l}-0.066 \\
(0.043)\end{array}$ & $\begin{array}{l}-0.044 \\
(0.043)\end{array}$ & $\begin{array}{l}-0.057 \\
(0.042)\end{array}$ & $\begin{array}{l}-0.051 \\
(0.043)\end{array}$ \\
\hline Employed & & & $\begin{array}{l}-0.023 \\
(0.050)\end{array}$ & $\begin{array}{l}-0.004 \\
(0.049)\end{array}$ & $\begin{array}{l}-0.008 \\
(0.050)\end{array}$ & $\begin{array}{c}-0.0004 \\
(0.049)\end{array}$ \\
\hline Unemployed & & & $\begin{array}{l}-0.027 \\
(0.056)\end{array}$ & $\begin{array}{l}-0.027 \\
(0.054)\end{array}$ & $\begin{array}{l}-0.017 \\
(0.055)\end{array}$ & $\begin{array}{l}-0.030 \\
(0.054)\end{array}$ \\
\hline SES & & & $\begin{array}{c}0.008 \\
(0.020)\end{array}$ & $\begin{array}{c}0.004 \\
(0.019)\end{array}$ & $\begin{array}{c}0.006 \\
(0.019)\end{array}$ & $\begin{array}{c}0.005 \\
(0.019)\end{array}$ \\
\hline Married/Widowed & & & $\begin{array}{c}-0.151^{* * *} \\
(0.054)\end{array}$ & $\begin{array}{c}-0.158^{* * *} \\
(0.050)\end{array}$ & $\begin{array}{c}-0.157^{* * *} \\
(0.051)\end{array}$ & $\begin{array}{c}-0.158^{* * *} \\
(0.051)\end{array}$ \\
\hline Constant & $\begin{array}{c}0.073 \\
(0.093)\end{array}$ & $\begin{array}{c}0.149 \\
(0.097)\end{array}$ & $\begin{array}{c}0.147 \\
(0.132)\end{array}$ & $\begin{array}{c}0.195 \\
(0.134)\end{array}$ & $\begin{array}{c}0.183 \\
(0.136)\end{array}$ & $\begin{array}{c}0.212 \\
(0.135)\end{array}$ \\
\hline Governorate FEs & Yes & Yes & Yes & Yes & Yes & Yes \\
\hline Observations & 744 & 742 & 742 & 740 & 742 & 740 \\
\hline Adjusted $\mathrm{R}^{2}$ & 0.057 & 0.089 & 0.063 & 0.093 & 0.087 & 0.095 \\
\hline
\end{tabular}


2014 Presidential Elections - Runoff

Table A.6: Correlates of Essebsi Voting

\begin{tabular}{|c|c|c|c|c|c|c|}
\hline & \multicolumn{6}{|c|}{ Dependent variable: } \\
\hline & \multicolumn{6}{|c|}{ Voted for Sebsi (2014 runoff) } \\
\hline & $(1)$ & $(2)$ & $(3)$ & $(4)$ & $(5)$ & $(6)$ \\
\hline Arrested & $\begin{array}{c}-0.122^{* *} \\
(0.057)\end{array}$ & & $\begin{array}{c}-0.134^{* *} \\
(0.057)\end{array}$ & & & $\begin{array}{l}-0.158 \\
(0.118)\end{array}$ \\
\hline Knows Someone Arrested & & $\begin{array}{c}-0.175^{* * *} \\
(0.025)\end{array}$ & & $\begin{array}{c}-0.164^{* * *} \\
(0.025)\end{array}$ & & $\begin{array}{c}-0.162^{* * *} \\
(0.026)\end{array}$ \\
\hline Arrested*Knows Someone Arrested & & & & & & $\begin{array}{c}0.111 \\
(0.130)\end{array}$ \\
\hline Family Member Arrested & & & & & $\begin{array}{c}-0.076^{* *} \\
(0.036)\end{array}$ & \\
\hline Neighbors Arrested & & & & & $\begin{array}{c}-0.135^{* * *} \\
(0.039)\end{array}$ & \\
\hline Community Member Arrested & & & & & $\begin{array}{c}-0.082^{* *} \\
(0.036)\end{array}$ & \\
\hline Female & $\begin{array}{l}0.041^{*} \\
(0.023)\end{array}$ & $\begin{array}{c}0.020 \\
(0.022)\end{array}$ & $\begin{array}{c}0.054^{* *} \\
(0.026)\end{array}$ & $\begin{array}{l}0.043^{*} \\
(0.025)\end{array}$ & $\begin{array}{c}0.054^{* *} \\
(0.025)\end{array}$ & $\begin{array}{c}0.038 \\
(0.025)\end{array}$ \\
\hline Age & $\begin{array}{c}0.006^{* * *} \\
(0.001)\end{array}$ & $\begin{array}{c}0.006^{* * *} \\
(0.001)\end{array}$ & $\begin{array}{c}0.007^{* * *} \\
(0.001)\end{array}$ & $\begin{array}{c}0.007^{* * *} \\
(0.001)\end{array}$ & $\begin{array}{c}0.007^{* * *} \\
(0.001)\end{array}$ & $\begin{array}{c}0.007^{* * *} \\
(0.001)\end{array}$ \\
\hline Secondary+ Education & & & $\begin{array}{c}-0.117^{* * *} \\
(0.031)\end{array}$ & $\begin{array}{c}-0.093^{* * *} \\
(0.031)\end{array}$ & $\begin{array}{c}-0.110^{* * *} \\
(0.031)\end{array}$ & $\begin{array}{c}-0.097^{* * *} \\
(0.031)\end{array}$ \\
\hline Employed & & & $\begin{array}{c}0.022 \\
(0.032)\end{array}$ & $\begin{array}{c}0.040 \\
(0.032)\end{array}$ & $\begin{array}{c}0.033 \\
(0.031)\end{array}$ & $\begin{array}{c}0.043 \\
(0.032)\end{array}$ \\
\hline Unemployed & & & $\begin{array}{c}0.033 \\
(0.042)\end{array}$ & $\begin{array}{c}0.036 \\
(0.042)\end{array}$ & $\begin{array}{c}0.043 \\
(0.042)\end{array}$ & $\begin{array}{c}0.037 \\
(0.042)\end{array}$ \\
\hline SES & & & $\begin{array}{l}0.026^{*} \\
(0.015)\end{array}$ & $\begin{array}{c}0.022 \\
(0.015)\end{array}$ & $\begin{array}{c}0.021 \\
(0.015)\end{array}$ & $\begin{array}{c}0.024 \\
(0.015)\end{array}$ \\
\hline Married/Widowed & & & $\begin{array}{c}-0.076^{*} \\
(0.045)\end{array}$ & $\begin{array}{c}-0.072^{*} \\
(0.043)\end{array}$ & $\begin{array}{c}-0.075^{*} \\
(0.043)\end{array}$ & $\begin{array}{c}-0.072^{*} \\
(0.043)\end{array}$ \\
\hline Constant & $\begin{array}{c}0.470^{* * *} \\
(0.072)\end{array}$ & $\begin{array}{c}0.521^{* * *} \\
(0.077)\end{array}$ & $\begin{array}{c}0.443^{* * *} \\
(0.092)\end{array}$ & $\begin{array}{c}0.464^{* * *} \\
(0.095)\end{array}$ & $\begin{array}{c}0.464^{* * *} \\
(0.097)\end{array}$ & $\begin{array}{c}0.469^{* * *} \\
(0.095)\end{array}$ \\
\hline Governorate FEs & Yes & Yes & Yes & Yes & Yes & Yes \\
\hline Observations & 1,199 & 1,196 & 1,194 & 1,191 & 1,196 & 1,190 \\
\hline Adjusted $\mathrm{R}^{2}$ & 0.163 & 0.188 & 0.177 & 0.197 & 0.189 & 0.198 \\
\hline
\end{tabular}




\section{Proposed Survey: Sample of Survey Instrument on Repression and Family Legacies}

We ask several questions about the respondent's previous political activism and experiences with state repression. The same questions are then asked about the respondent's immediate family, extended family. We also ask about the repression of friends and member of the community.

- Many people changed political affiliations after 2011. But before 2011, were you (your immediate family, your extended family) a member of any of the following parties or political movements? (Check all that apply)

- Before 2011, did you (your immediate family, your extended family) hold public office (either elected (municipal council) or administrative (governor))?

- Before 2011, were you (your immediate family, your extended family, your friends, members of your community) imprisoned, placed under house arrest, kidnapped, exiled, or punished economically (such as losing a job, losing a contract, or paying a fine) because of your political activities? Check all that apply

We also ask about the extent to which respondents discuss repression and politics with their families and the extent to which they identify as victims.

- How often do you discuss politics with the following types of people: Your family, Your friends, Your co-workers, Your neighbors, People you don't know well

- Growing up, how often did your immediate family discuss repression with you?

- To what extent do you consider yourself and your relatives to be victims of the Bourguiba regime?

- To what extent do you consider yourself and your relatives to be victims of the Ben Ali regime? 